\title{
STEM QUALITY OF EUROPEAN BEECH IN LATVIA AND ITS EFFECT ON TREE AND STAND MONETARY VALUE
}

\author{
Diāna Jansone, Luīze Diena, Raitis Rieksts-Riekstiṇš, and Āris Jansons ${ }^{\#}$ \\ Latvian State Forest Research Institute "Silava", 111 Rīgas Str., Salaspils, LV-2169, LATVIA \\ \# Corresponding author: aris.jansons@silava.Iv
}

Contributed by Āris Jansons

\begin{abstract}
Beech is expected to expand its range into the territory of Latvia due to climate change, but we lack information on its stem and wood quality as a measure of its economic importance. We studied external stem quality traits in beech stands with age of 69 to 131 years. Nine trees were cut and sampled to determine internal wood quality and the proportion of peelable cylinder. Tree value was calculated according to buckling by dimensions and buckling accounting for stem and wood defects. Trees of the second generation (69 years) had a significantly lower incidence of frost cracks (22.0\% vs. $36.2 \%)$, epicormic branches (50.5 \% vs. $65.8 \%)$, and forks $(15.8 \%$ vs. $23.5 \%)$ as compared to trees from the first generation (115-131 years). All sampled trees had discolouration in the height of the first log. The proportion of the peelable cylinder was positively linked to tree height and ranged from 12\% at the stump level to $33.4 \%$ at the tree height of $30 \mathrm{~m}$. All analysed phenotypic traits decreased stand monetary value: frost cracks by $6 \%$ to $8 \%$, all external traits by $16 \%$ to $20 \%$, all external and internal traits by $29 \%$ to $33 \%$.
\end{abstract}

Keywords: buckling, wood defects, peelable cylinder, Fagus sylvatica, value reduction.

\section{INTRODUCTION}

The natural range of European beech (Fagus sylvatica L.) (von Wühlisch, 2008) could gradually expand its northeastern border under the ongoing climate change. The main limiting meteorological factors that affect the radial growth of beech are winter temperature and precipitation at the end of summer (Jansons et al., 2015), and these are expected to become favourable for beech; thus it could increase its range in the territory of Latvia (Hickler et al., 2012; Purina et al., 2016). The use of beech in forest regeneration during the last decades has increased in central Europe, mainly due to its lower sensitivity to the negative effects of climate change in comparison to other economically important tree species (Piętka et al., 2019). Beech has relatively higher resistance to wind damage (Bergmeier and Dimopoulos, 2001; Schutz et al., 2006), less pronounced effect of summer drought on radial growth (Merela et al., 2005), and lower susceptibility to dendrophagous insects (von Wühlisch et al., 2008; Purina et al., 2013). In Latvia, European beech was first introduced in parks and dendrological gardens (Vanders, 1960). The largest stands from these introductions have remained in Škede district, where the for- est area of beech consists of first-generation trees (i.e. trees from foreign stock that were planted) along with the trees of the second generation, originating from natural regeneration, forming younger stands (Dreimanis, 2006; Jansone, 2019).

The lack of information on beech stem quality and, consequently, on its economic potential for roundwood production, hinders landowner interest in its wider use over Northern Europe. Traits that most affect the financial value of beech stem are dimensions, stem straightness, low number of branches, and absence of defects such as butt swell, discolouration, and false heartwood (von Wühlisch, 2008). The quality of beech wood has been shown to be affected by specific site and weather conditions (Bouriaud et al., 2004; Wernsdörfer, 2006; Wernsdörfer et al., 2006; Skarvelis and Mantanis, 2010; Câmpu et al., 2013; Kúdela et al., 2014; Câmpu et al., 2015). However, studies in the northern regions of the beech distribution range have minimally looked at these aspects (Purina et al., 2017; Bergkvist, 2019).

This study aimed to assess the phenotypic characteristics that affect the assortment outcome of European beech in 
stands in the western part of Latvia. For this, we collected data on traits that affect the value of the tree (dimensions, branching, presence of stem cracks, and other visual defects) and assessed visual wood defects in sample disks and for the whole stem.

\section{MATERIALS AND METHODS}

Study area. The study was conducted in the Forest Research Station forests $\left(57^{\circ} 14^{\prime} \mathrm{N}, 22^{\circ} 41^{\prime} \mathrm{E}\right)$ in the largest stands of European beech in Latvia.

Field sampling. Data was collected in eight beech stands at the age of 69 to 131 years (Table 1), which were established on easily drained mineral soil (Oxalidosa forest type). In total, 13 sample plots (area $500 \mathrm{~m}^{2}$ ) were randomly established, each at a distance from stand edge of at least $15 \mathrm{~m}$. In each sample plot, diameter at the breast height $(\mathrm{DBH})$ of all canopy layer trees was measured, and stem quality was assessed.

Stem straightness for a $\log$ of $6 \mathrm{~m}$ from the root collar was visually evaluated and scored from 1 (the least straight, no $\log$ can be acquired) to 7 (very straight, a $\log$ of $\geq 5 \mathrm{~m}$ can be acquired), as applied from Price et al. (2017). The number of branches of diameter $\leq 4 \mathrm{~cm}$ and $>4 \mathrm{~cm}$ located at a height up to $6 \mathrm{~m}$, and epicormic shoots were assessed, scoring from 1 for no branches, 2 for $\leq 10$ branches, and 3 for $>10$ branches on a stem. For the same tree height, forks were noted and cracks on the stem were counted. The presence (binary) of stem damage on growing trees was recorded: root-buttress concavities, dead branches in the tree crown, enclosed bark, frost cracks, and others (woodpecker cavities, rot holes, insect galleries, exposed sapwood, exposed sapwood and heartwood, burrs and cankers, perennial fungi fruiting bodies, ephemeral fungi fruiting bodies, epiphytic structures, and parasites, nests, and exudates).

For assessment of internal wood quality, 108 disks with a thickness of two to four centimetres from nine trees were cut and collected at every 3-m length of a stem in a 91year-old stand. The disks were stored in a freezer to avoid cracks during drying. The area of the disk (cross-section of the stem) and the smallest length from the heartwood to the edge of the disk were measured.

Data analysis. Stem volume was calculated using the equation for beech by Sodtke et al. (2003). Assortments were calculated using the local buckling algorithm developed by Ozolins (2002). There is currently no market for beech timber in Latvia, and thus assortment dimensions and prices from central Europe were applied (Table 2).

Based on the results of the inventory of sample plots and information found in literature, several assumptions were made for the buckling of stems with defects:

1) if a tree had a crack, the first log corresponded to packaging wood;
Table 1. Characteristics of the studied stands

\begin{tabular}{ccccccc}
\hline $\begin{array}{c}\text { Stand } \\
\text { no. }\end{array}$ & $\begin{array}{c}\text { Cadastral block } \\
\text { compartment }\end{array}$ & Compartment & $\begin{array}{c}\text { Area, } \\
\text { ha }\end{array}$ & $\begin{array}{c}\text { Number } \\
\text { of plots }\end{array}$ & $\begin{array}{c}\text { Stand } \\
\text { age }\end{array}$ \\
\hline 1 & 21 & 28 & 0.37 & 1 & 130 \\
2 & 21 & 26 & 0.34 & 1 & 91 \\
3 & 21 & 1 & 1.48 & 2 & 131 \\
4 & 26 & 8 & 1.97 & 2 & 115 \\
5 & 26 & 7 & 0.54 & 1 & 115 \\
6 & 23 & 29 & 5.20 & 2 & 120 \\
7 & 14 & 18 & 0.62 & 2 & 104 \\
8 & 14 & 3 & 2.18 & 2 & 69
\end{tabular}

Table 2. Assortment dimensions and prices for European beech assortments (length $3 \mathrm{~m}$ ), applied from Tabelle Holzpreise (2019)

\begin{tabular}{l|c|c|c|c}
\hline Assortment & $\begin{array}{c}\text { Diameter at } \\
\text { the narrower } \\
\text { end, cm }\end{array}$ & $\begin{array}{c}\text { Presence } \\
\text { of bark }\end{array}$ & $\begin{array}{c}\text { Highest } \\
\text { price, } \\
\text { EUR }\end{array}$ & $\begin{array}{c}\text { Lowest price, } \\
\text { EUR }\end{array}$ \\
\hline Sawlog I & $\geq 35$ & without & 108 & 75 \\
Sawlog II & $30-34$ & without & 73 & 66 \\
Sawlog III & $18-29$ & without & 64 & 58 \\
Packaging wood & $14-18$ & without & 42 & 34 \\
Firewood & $6-14$ & with & 30 & 24
\end{tabular}

2) if a tree had epicormic shoots, both the first and the second $\log$ s corresponded to second-class;

3) if a tree had cavities or holes, the first log corresponded to packaging wood;

4) if a tree had a fork, one second-class sawlog corresponded to packaging wood;

5) if a tree had curvature (crooked stem), both sawlogs corresponded to second-class.

The proportion of peelable cylinder, i.e. inner cylinder of a $\log$ that is suitable for veneer peeling, which could be attained from the log volume at different stem heights, was calculated using the measurements at the top end of a particular log.

The occurrence of cracks (proportion of trees with cracks) and tree branching (occurrence of various defects and their total occurrence) in different age groups were analysed using a $\chi^{2}$ test. The proportion of false heartwood and heartwood at different heights was determined.

\section{RESULTS}

Incidence of stem defects. The incidence of trees with stem defects was high in both mature (104-131 years) and middle-aged (69-91 years) stands. Mature stands had a slightly but non-significantly $(p>0.05)$ higher incidence of trees with stem defects: only $23.2 \%$ of trees were intact in comparison to $28.8 \%$ in middle-aged stands.

Among the stem damage types, stem cracks were the most common type of defect and were found on $22 \%$ of trees in 


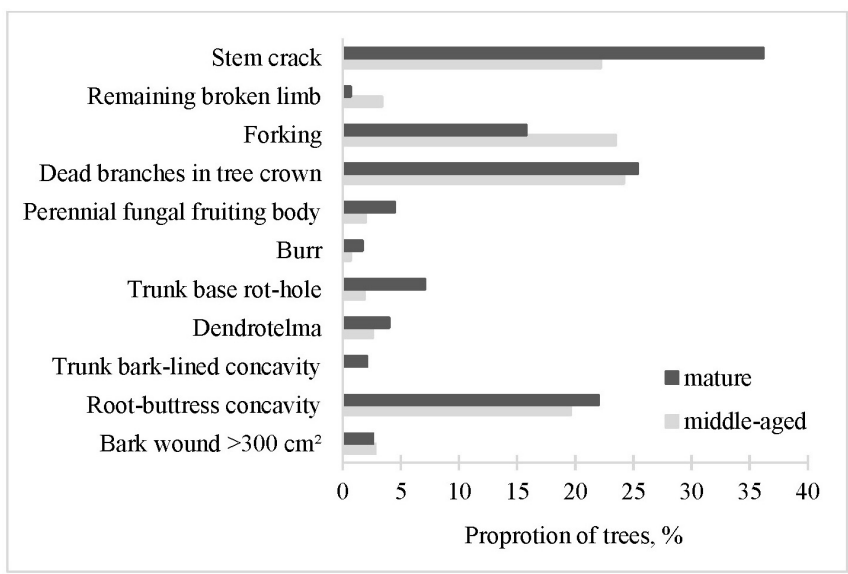

Fig. 1. The proportion of trees with various stem defects in middle-aged (69-91 years) and mature (104-131 years) stands.

middle-aged stands and $36 \%$ of trees in mature stands (Fig. $1)$. The occurrence of stem cracks was more common on dominant trees. Root-buttress concavities were noted for $19.6 \%$ of trees in middle-aged stands and $22.0 \%$ of trees in mature stands, with a maximum of six concavities per tree. Other common defects affecting tree vitality were dead branches in a tree crown and branching (forks). Other external defects were observed on less than $5 \%$ of trees.

Tree crown and branching. The largest proportion of trees with dead branches in the crown was observed in stands at the age of 69 years $(40.8 \%)$, significantly greater that in stands at the age of 91-104 years (16.2\%) and 115-131 years $(22.8 \%)$.

Epicormic branches were most common (65.8\% of trees) in stands at the age of 115-131 years, and significantly ( $p<$ $0.05)$ decreased in younger stands. In the oldest stands, $47.0 \%$ of trees with epicormic branches had more than 10 of these branches located from the stem base up to $6 \mathrm{~m}$ in height. In stands at the age of 91-104 years, epicormic branches were present on $52.6 \%$ of trees, among which $25.0 \%$ had more than 10 epicormic branches on the bottom $\log$. In the youngest stands, epicormic branches were found on $50.5 \%$ of trees, among which $20.8 \%$ had more than 10 epicormic branches on the bottom log.

Occurrence of trees with thin $(<4 \mathrm{~cm})$ and thick $(>4 \mathrm{~cm})$ branches located on the lower 6-m height of a stem showed no age-related trends. The proportion of trees with no branches in this height class was $98.1 \%, 81.6 \%$, and $89.3 \%$ at the ages of $69,91-104$, and 115-131 years. For groups of stands in ascending age, thin branches were noted on $1.9 \%$, $9.2 \%$, and $8.7 \%$ of trees and thick branches were noted for $0 \%, 9.2 \%$, and $2.0 \%$ of trees, respectively.

Proportion of heartwood and peelable cylinder. None of the sampled trees was qualified as a first-grade sawlog, as all trees had discolouration and heartrot. The proportion of discoloured area significantly decreased from the stem base towards the top (Fig. 2), and was in the range from $46.5 \%$ at tree height of $3 \mathrm{~m}$ to $7.5 \%$ at a tree height of $30 \mathrm{~m}$. The pro-

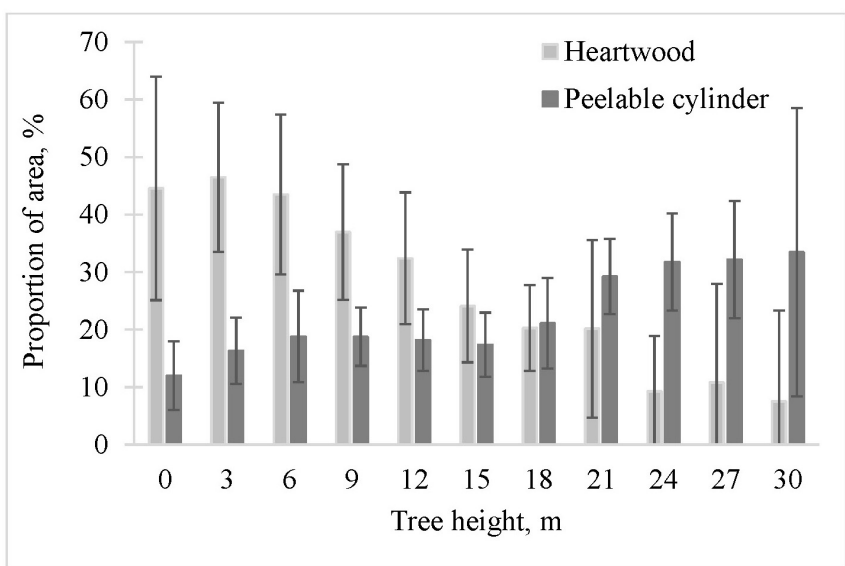

Fig. 2. The proportion of heartwood and peelable cylinder of a cross-cut area at different stem height $( \pm 95 \%$ confidence interval).

portion of peelable cylinder had the opposite trend, and increased from $12.0 \%$ at the stump level to $33.4 \%$ at tree height of $30 \mathrm{~m}$.

Stem straightness was best in middle-aged stands, where a higher proportion of trees was evaluated in the higher three grades of stem straightness: $22.2 \%$ in Grade 7 (the most straight), $26.8 \%$ in Grade 6, and $18.3 \%$ in Grade 5. Stem straightness was insufficient (Grade 1; no log can be acquired) for $11.1 \%$ of trees. In mature stands, $18.1 \%$ of trees were evaluated in Grade 7, 26.6\% in Grade 6, and $13.0 \%$ in Grade 5, whereas the poorest stem straightness was found for $19.7 \%$ of trees.

Effect of stem defects on the financial outcome. Only one of nine sampled trees had sufficient dimensions (DBH $40 \mathrm{~cm}$ ) for a first-grade sawlog, and four trees were suitable (DBH 30-34 cm) for a second-grade sawlog (Table 3). For the sampled trees, the highest proportion of the volume corresponded to a third-grade sawlog $(40.4 \%$ to $81.2 \%$ of timber volume). Consequently, the proportion of packaging wood and firewood was larger for trees with smaller DBH, and gradually decreased with lower $\mathrm{DBH}$ from $37.5 \%$ to $6.8 \%$ (both assortments pooled).

The sampled trees had several internal and external wood defects: enclosed bark, soft rot $(<20 \%$ of the area), discolouration (from $25.0 \%$ to $34.6 \%$ of the area), forking, and frost crack. When these defects were considered into buckling, only one tree did not differ in assortment outcome (Table 3) and for all sampled trees the volume of first- and second-grade sawlogs was lower. The largest increase in volume was shown for firewood, which increased by $28.6 \%$ to $800.0 \%$. Changes in assortment outcome reduced individual tree value by $1.7 \%$ to $25.0 \%$, as compared to assortments from the same trees when no defects are considered.

Stand financial outcome. Financial value was calculated for stands at the age of 115 years. The most common quality defects in these stands were epicormic branches $(53.1 \%$ of trees), stem cracks $(43.8 \%)$, crooked stem (21.9\%), forking $(28.1 \%)$, and rot $(9.4 \%)$. While cracks and epicormic 
Table 3. Dimensions, assortment outcome, and tree value of the sampled trees if stem and wood defects are not considered and changes in timber assortment outcome and loss of timber value due to stem and wood quality defects

\begin{tabular}{|c|c|c|c|c|c|c|c|c|c|c|c|c|c|c|c|c|c|}
\hline \multirow[t]{2}{*}{$\begin{array}{c}\text { Tree } \\
\text { no. }\end{array}$} & \multirow[t]{2}{*}{$\begin{array}{c}\mathrm{DBH}, \\
\mathrm{cm}\end{array}$} & \multirow[t]{2}{*}{$\begin{array}{l}\mathrm{H}, \\
\mathrm{m}\end{array}$} & \multirow[t]{2}{*}{$\begin{array}{c}\text { Volume, } \\
\mathrm{m}^{3}\end{array}$} & \multicolumn{5}{|c|}{$\begin{array}{c}\text { Timber volume, } \\
\mathrm{m}^{3}\end{array}$} & \multicolumn{5}{|c|}{$\begin{array}{l}\text { Changes in timber volume due to defects, } \\
\qquad \mathrm{m}^{3}\end{array}$} & \multicolumn{2}{|c|}{$\begin{array}{l}\text { Potential tree } \\
\text { value, EUR }\end{array}$} & \multicolumn{2}{|c|}{$\begin{array}{l}\text { Tree value, } \\
\text { EUR }\end{array}$} \\
\hline & & & & SL I & SL II & SL III & $\mathrm{PT}$ & FW & SL I & SL II & SL III & PT & FW & $\begin{array}{l}\text { High } \\
\text { price }\end{array}$ & $\begin{array}{l}\text { Low } \\
\text { price }\end{array}$ & $\begin{array}{l}\text { High } \\
\text { price }\end{array}$ & $\begin{array}{l}\text { Low } \\
\text { price }\end{array}$ \\
\hline 1 & 30 & 30 & 0.85 & 0 & 0 & 0.69 & 0.07 & 0.09 & 0 & 0 & 0 & -0.07 & 0.07 & 49.80 & 44.60 & 0.84 & 0.74 \\
\hline 2 & 20 & 26 & 0.56 & 0 & 0 & 0.35 & 0.14 & 0.07 & 0 & 0 & 0 & -0.07 & 0.07 & 30.40 & 26.74 & 2.36 & 1.9 \\
\hline 3 & 32 & 35 & 1.12 & 0 & 0 & 0.82 & 0.18 & 0.12 & 0 & 0 & -0.24 & 0 & 0.24 & 63.64 & 56.56 & 8.16 & 8.16 \\
\hline 4 & 32 & 35 & 1.12 & 0 & 0 & 0.82 & 0.18 & 0.12 & 0 & 0 & 0 & 0 & 0 & 63.64 & 56.56 & 0 & 0 \\
\hline 5 & 34 & 36 & 1.29 & 0 & 0.23 & 0.82 & 0.16 & 0.08 & 0 & -0.23 & 0.23 & 0 & 0 & 78.39 & 70.10 & 2.07 & 1.84 \\
\hline 6 & 36 & 34 & 1.38 & 0 & 0.49 & 0.76 & 0.07 & 0.06 & 0 & -0.49 & 0.34 & 0 & 0.15 & 89.15 & 80.24 & 9.51 & 9.02 \\
\hline 7 & 40 & 32 & 1.61 & 0.32 & 0.53 & 0.65 & 0.07 & 0.04 & -0.32 & -0.53 & 0.53 & 0 & 0.32 & 118.99 & 100.02 & 29.73 & 20.56 \\
\hline 8 & 36 & 34 & 1.38 & 0 & 0.49 & 0.76 & 0.07 & 0.06 & 0 & -0.49 & 0.25 & 0 & 0.24 & 89.15 & 80.24 & 12.57 & 12.08 \\
\hline 9 & 30 & 30 & 0.85 & 0 & 0 & 0.69 & 0.07 & 0.09 & 0 & 0 & -0.24 & 0 & 0.24 & 49.80 & 44.60 & 8.16 & 8.2 \\
\hline
\end{tabular}

SL, saw log; PT, packaging timber; FW, fire wood.

branches were found in most $\mathrm{DBH}$ classes, rot was observed only for trees larger than $56 \mathrm{~cm}$, forking was more common for medium-sized and large trees (larger than $36 \mathrm{~cm}$ ), and crooked stems were mostly found for trees smaller than $24 \mathrm{~cm}$ with some crooked trees at DBH classes 44 and $68 \mathrm{~cm}$.

When only stem cracks were considered in buckling, the timber value of a stand was reduced by $7.7 \%$ under the high price and $6.1 \%$ under the low price scenario (Fig. 3). When all external defects were considered, the stand value reduction increased to $19.8 \%$ and $16.2 \%$ for high and low prices, respectively. However, when both external and internal wood defects (discolouration and rot) were considered in buckling, the stand value dropped by $33.0 \%$ (high price) and $29.1 \%$ (low price), as compared to the same stands with no wood defects.

\section{DISCUSSION}

The results revealed substantial effect of stem morphological appearance and internal wood features on timber assortment outcome and stand value. Beech has shown high productivity in Latvia with standing volume from 424 to 786 $\mathrm{m}^{3} \cdot \mathrm{ha}^{-1}$ at the age of 91 to 115 years (Dreimanis, 2006). A previous study showed higher income from stands at the age of 115 years as compared to the age of 58 years (Purina et $a l ., 2017$ ), but used only stem dimensions in buckling. Our analysed stand was in the typical rotation age range (80 to 120 years) of beech (von Wühlisch et al., 2008), and the age-related stem and wood defects had a significant effect on individual tree and stand value, indicating that it might not be profitable to extend the rotation age.

Regardless of the age of the stands, trees had not reached sufficient dimensions for first-grade sawlogs, neither in our study, nor in the previous study in Latvia (Purina et al., 2017). Similarly with our results, negligible outcome (6\% to $9 \%$ ) of second-grade sawlogs was previously observed, while the most volume was compiled by third-grade saw-

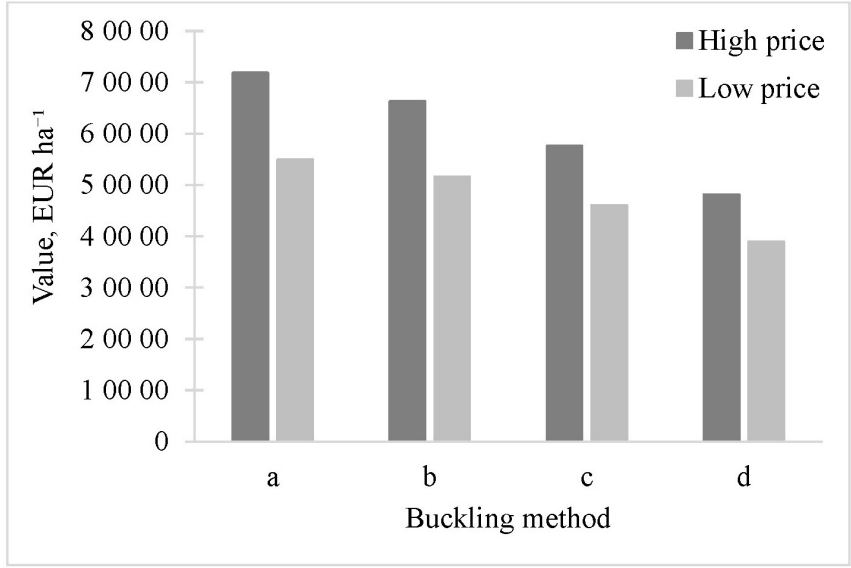

Fig. 3. Stand value under different buckling methods, accounting for (a) dimensions only or considering (b) stem cracks, (c) external defects, and (d) all external and internal defects.

logs (Puringa et al., 2017). Comparable results are obtained in a study of beech stands at the age of 91-160 years in Poland (Karaszewski et al., 2013). They found the third category logs (four categories in total) were the most common assortment, and together with fourth-grade logs they formed $82 \%$ of the total assortment outcome, while first- and second-quality $\operatorname{logs}$ formed $3 \%$ and $15 \%$, respectively. Low yield of the veneer quality logs and sawlogs was also observed in mature stands in Slovenia (Poljanec and Kadunc, 2013), where they compiled $2.6 \%$ of the analysed trees, while $22.9 \%$ of trees were classified as having excellent and very good quality. Our results and the cited studies indicate similar trends. However, different studies should be compared with caution, as the local quality grades and standards might differ.

The yield of higher-graded assortments might be increased by management measures (Poljanec et al., 2010), particularly by removal of low-quality trees during the thinning from above (Hein et al., 2007). Special precaution should be paid to most commonly present defects, as they have a 
stronger effect on assortment quality assessment. Considering the lack of management that was conducted in our studied sites, it can be presumed that under more intense management, the yield of higher-grade assortments might be higher. Indeed, Poljanec and Kadunc (2013) found that the harvesting intensity in the last ten-year period was positively associated with higher value of beech wood.

Stem cracks were the most frequently noted type of stem defect in our study, as observed to be common in central Europe (Câmpu et al., 2013). Cracks are formed during the winter when the water inside cells freezes, causing the bark and outer layer of wood to crack lengthwise along the stem. Thus, their formation might be a consequence of beech growing at the northern border of its natural range. Our results of higher incidence of cracks in mature as compared to middle-aged stands, i.e. more common for planted trees from foreign stock, suggest that the next-generation trees might already have adapted to some extent, supporting the previously reported adaptability of beech to a changing climate (Dimitrov, 2019). Lower sensitivity of the second-generation beech was also shown in a previous study conducted near the studied stands (Jansone, 2019).

In most susceptible trees, several cracks might occur, forming frost-crack stellar hearts (Câmpu et al., 2013). As this process might occur repeatedly every year, a tree can have difficulty in recovering, and there is a risk of infection. The presence of frost cracks significantly affects tree value, as their presence might lower assortment grading by two to three categories (Câmpu et al., 2013).

Another trait that significantly affected wood quality was the occurrence of knots, and it was among the four main quality-lowering traits in our study. Their negative effect might even be higher, as we only noted visible knots, and covered knots might not have been recognised in our assessment. A study by Karaszewski et al. (2013) showed that covered knots can be as high as $15-20 \%$ of all knots.

The occurrence of knots might be lowered by stand spacing and management, as it has been shown that dense spacing promotes natural thinning and consequently lowers the number of large knots (Ikonen et al., 2003). Smaller knots are preferred as they heal more rapidly (Hein, 2008), and in this case wood is exposed to fungal infections for a shorter time. Accordingly, we observed stem cracks to be associated with rot, although another study found scars to be weekly related to the incidence of red heart formation (Wernsdörfer et al., 2005).

Tree spacing can be controlled by thinning, but more studies are needed to determine the optimum, as improved growth conditions might cause the formation of epicormic branches, which lower wood quality in the stem periphery. Timber harvesting might also increase the occurrence of damage for the remaining trees (Poljanec and Kadunc, 2013). Such types of damage include wounds on bark, which similarly to cracks, increase the risk of red heart and rot.
Our studied trees had a high incidence of discolouration and subsequent high loss of usable wood; therefore, among external stem properties it can be considered as the main factor impeding yield planning. Discolouration is a common wood defect in beech also in its natural distribution area (Albert et al., 2003; Pöhler et al., 2005). As many as 85\% of logs in the final felling have this defect, which might cover as much as $91 \%$ of the log cross-cut (mean $18 \%$, Knoke et al., 2006). In mature beech stands in Poland, red heart was less common than (in descending order) knots, sweep, and scars on a bark, yet more frequently noted than spiral grain, double pit, and rot (Karaszewski et al., 2013).

Discolouration tends to be more common in larger and older trees (Wernsdörfer et al., 2006). Concerning that all sampled trees had significant discolouration, a prolonged rotation period should be considered with caution. Although trees might reach dimensions for higher-graded (veneer) assortments, stem damage would increase during this time, diminishing the benefit of a thicker stem.

This study aimed to provide insight into the potential of beech timber production in Latvia. As there is no local market for beech timber, calculations should not be assumed to provide a precise monetary value. However, they show the importance of wood quality on timber value and indicate quality traits that should be considered during stand establishment (e.g., adapted planting stock and rather dense spacing) and its management (e.g., timing of thinning) to increase individual tree and stand monetary value.

\section{ACKNOWLEDGMENTS}

This research was funded in accordance to a cooperation agreement in scientific research between JSC "Latvia's State Forests" and LSFRI "Silava" in the project "Support for Forest Tree Seed Production".

\section{REFERENCES}

Albert, L., Hofmann, T., Nemeth, Z. I., Retfalvi, T., Koloszar, J., Varga, S., Csepregi, I. (2003). Radial variation of total phenol content in beech (Fagus sylvatica L.) wood with and without red heartwood. Holz als Rohund Werkstoff, 61, 227-230.

Bergmeier, E., Dimopoulos, P. (2001). Fagus sylvatica forest vegetation in Greece: Syntaxonomy and gradient analysis. J. Vegetat. Sci., 12, 109-126.

Bergkvist, J. (2019). Growth and timber quality evaluation of 33 European beech (Fagus sylvatica L.) provenances from a site in Southern Sweden. Master thesis. Southern Swedish Forest Research Centre, Faculty of Forest Sciences. https://stud.epsilon.slu.se/15092/ (accessed 10.08.2021.)

Bouriaud, O., Breda, N., Le Moguedec, G., Nepveu, G. (2004). Modelling variability of wood density in beech as affected by ring age, radial growth and climate. Trees, 18, 264-276.

Câmpu, V. R., Dumitrache, R. (2013). Frost-crack frequency in beech stands. Bulletin of the Transilvania University of Brasov. Series II, 6 (2), 9.

Câmpu, V. R., Dumitrache, R. (2015). Frost crack impact on European beech (Fagus sylvatica L.) wood quality. Notulae Botanicae Horti Agrobotanici Cluj-Napoca, 43 (1), 272-277. 
Dimitrov, D. P. (2019). Dendrochronology of 358-years-old European beech (Fagus sylvatica $\mathrm{L}$.) forest stand from tree-line zone of the Balkan range mountain, Bulgaria. Silva Balcanica, 20 (3), 19-26.

Dreimanis, A. (2006). Dižskābarža mežaudžu ražību Šḳēdes novadā [Productivity of beech stands in Škēede district]. LLU Raksti, 16 (311), 97-100 (in Latvian).

Hein, S. (2008). Knot attributes and occlusion of naturally pruned branches of Fagus sylvatica. Forest Ecol. Manag., 256 (12), 2046-2057.

Hein, S., Lenk, E., Klädtke, J., Kohnle, U. (2007). Selection thinning in beech (Fagus sylvatica L.): Effects on quality, stand structure and value performance [Z-Baum-orientierte Auslesedurchforstung in Buche (Fagus sylvatica L.), Auswirkungen auf Qualität, Sortenstruktur und Wertleistung]. Allg. Forst- u. Jagd-Ztg., 178 (11), 8-20 (in German).

Hickler, T., Vohland, K., Feehan, J., Miller, P. A., Smith, B., Costa, L., Giesecke, T., Fronzek, S., R. Carter, T. R., Cramer, W., Kühn, I., Sykes, M. T. (2012). Projecting the future distribution of European potential natural vegetation zones with a generalized, tree species-based dynamic vegetation model. Global Ecol. Biogeogr., 21 (1), 50-63.

Ikonen, V. P., Kellomäki, S., Peltola, H. (2003). Linking tree stem properties of Scots pine (Pinus sylvestris L.) to sawn timber properties through simulated sawing. Forest Ecol. Manag., 174, 152-263.

Jansone, L. (2019). Eiropas dižskābarža (Fagus sylvatica L.) kokaudžu atjaunošanās un augšana Latvijā [Regeneration and growth of European beech (Fagus sylvatica L.) stands in Latvia]. Latvijas mežzinātnes institūts "Silava", 45 lpp. (in Latvian).

Jansons, Ā., Matisons, R., Puriņa, L., Neimane, U., Jansons, J. (2015). Relationships between climatic variables and tree-ring width of European beech and European larch growing outside of their natural distribution area. Silva Fennica, 49 (1), 1255.

Karaszewski, Z., Bembenek, M., Mederski, P. S., Szczepanska-Alvarez, A., Byczkowski, R., Kozlowska, A., Michnowicz, K., Przytuła, W., Giefing, D. F. (2013). Identifying beech round wood quality - distributions and the influence of defects on grading. Drewno, 56 (189), 39-54.

Knoke, T., Stang, S., Remler, N., Seifert, T. (2006). Ranking the importance of quality variables for the price of high quality beech timber (Fagus sylvatica L.). Ann. Forest Sci., 63 (4), 399-413.

Kúdela, J., Gryc, V., Tóth, V. (2014). Deformation of beech wood - the sources and their identification before beech logs processing. Annals of Warsaw University of Life Sciences-SGGW. Forestry Wood Technol., 87, $121-125$.

Merela, M., Sepe, A., Oven, P., Sersa, I. (2005). Three-dimensional in vivo magnetic resonance microscopy of beech (Fagus sylvatica L.) wood. Magnetic Reson. Mater. Phys. Biol. Med., 18, 171-174.

Ozolins, R. (2002). Forest stand assortment structure analysis using mathematical modelling. Metsanduslikud Uurimused/Forestry Stud., 37, 33-42.

Piętka, J., Gendek, A., Mala'ák, J., Velebil, J., Moskalik, T. (2019). Effects of selected white-rot fungi on the calorific value of beech wood (Fagus sylvatica L.). Biomass Bioenergy, 127, 105290.

Pöhler, E., Klingner, R., Künniger, T. (2005). Beech (Fagus sylvatica L.) Technological properties, adhesion behaviour and colour stability with and without coatings of the red heartwood. Ann. Forest Sci., 63, 129-137.
Poljanec, A., Ficko, A., Boncina, A. (2010). Spatiotemporal dynamic of European beech (Fagus sylvatica L.) in Slovenia, 1970-2005. Forest Ecol. Manag., 259, 2183-2190.

Poljanec, A., Kadunc, A. (2013). Quality and timber value of European beech (Fagus sylvatica L.) trees in the Karavanke region. Croatian J. Forest Eng. J. Theory Appl. For. Eng., 34 (1), 151-165.

Price, A., Hapca, A., Gardiner, B., Macdonald, E., Mclean, P. (2017). Assessing the stem straightness of trees. Technical Note. Forestry Commission.

https://www.forestresearch.gov.uk/research/assessing-the-stem-straightness-of-trees/ (accessed 10.08.2021).

Puriņa, L., Dreimanis, A., Kārkliņa, A., Sisenis, L, Adamovičs, A., Puriṇš, M. (2017). Financial assessment of Fagus sylvatica stands in Latvia. Res. Rural Devel., 1, 81-85.

Puriņa, L., Matisons, R., Jansons, Ā., Šēnhofa, S. (2016). Survival of European beech in the central part of Latvia 33 years since the plantation. Silva Fennica, 50 (4), 1656.

Puriṇa, L., Neimane, U., Džeriṇa, B., Jansons, Ā. (2013). Eiropas dižskābarža (Fagus sylvatica L.) atjaunošanos ietekmējošie faktori [European beech (Fagus sylvatica L.) regeneration affecting factors]. Mežzinātne, 27 (60), 67-76 (in Latvian).

Schutz, J. P., Gotz, M., Schmid, W., Mandallaz, D. (2006). Vulnerability of spruce (Picea abies) and beech (Fagus sylvatica) forest stands to storms and consequences for silviculture. Eur. J. For. Res., 125, 91-130.

Skarvelis, M., Mantanis, G.I. (2010). Physical and mechanical properties of beech wood harvested in the greek public forests. Wood Res., 58 (1), 123-130.

Sodtke, R., Schmidt, M., Fabrika, M., Nagel, J., Dursky, J., Pretzsch, H. (2004). Anwendung und Einsatz von Einzelbaummodellen als Komponenten von entscheidungsunterstützenden Systemen für die strategische Forstbetriebsplanung. Forstarchiv, 75, 51-64.

Tabelle Holzpreise (2019). Langholz Buche, Rundholzpreise Stand. http://www.wald-prinz.de/holzpreise-und-holzpreisentwicklung-fichte/38 3 (accessed 10.08.2021).

Vanders, K. (1960). Eiropas dižskabāržu (Fagus sylvatica L.) introdukcijas sākums un gaita Latvijas PSR [Introduction of European beech in Latvia SSR]. Latvijas Lauksaimniecības Akadēmijas Raksti, 10, 503-512 (in Latvian).

Von Wühlisch, G. (2008). EUFORGEN Technical Guidelines for genetic conservation and use for European beech (Fagus sylvatca). Rome, Italy. $6 \mathrm{pp}$.

Wernsdörfer, H. (2006). Analysing red heartwood in Beech (Fagus sylvatica L.) related to external tree characteristics — towards the modelling of its occurrence and shape at the individual tree level. Life Sciences [q-bio], ENGREF (AgroParisTech), pastel-00001965. 100 pp.

Wernsdörfer, H., Le Moguedec, G., Constant, T., Mothe, F., Nepveu, G., Seeling, U. (2006). Modelling of the shape of red heartwood in beech trees (Fagus sylvatica L.) based on external tree characteristics. Ann. Forest Sci., 63, 905-913.

Wernsdörfer, H., Le Moguédec, G., Constant, T., Mothe, F., Seeling, U., Nepveu, G. (2005). Approach to the estimation of red heart occurrence in Fagus sylvatica based on geometric relationships between branch scar development and knot dimensions. Scand. J. Forest Res., 20, 448-455. 

VĒRTİBU

Klimata pārmaiņu kontekstā sagaidāma dižskābarža izplatības areāla paplašināšanās Latvijas teritorijā, bet tā ekonomiskās nozīmes analīzei trūkst informācijas par dižskābarža stumbra un koksnes kvalitāti. Pētījumā vērtētas stumbra ārējās pazīmes 69 līdz 131 gadu vecās dižskābarža audzēs. Deviņi koki nozāgeêti, no tiem ievākti paraugi koksnes iekšējās kvalitātes noteikšanai un lobīšanai piemērotās (iekrāsojuma neskartās) koksnes īpatsvara aprēḳināšanai. Aprēḳināta koka vērtība, n,emot vērā sortimentu iznākumu, kas noteikts pēc tā dimensijām, un sortimentu iznākumu, kas noteikts, n̦emot vērā stumbra un koksnes defektus. Dižskābarža otrās paaudzes (pēc introdukcijas Latvijā) kokiem (69 gadi), salīdzinājumā ar pirmās (115 līdz 131 gadi) paaudzes kokiem, bija būtiski retāk sastopamas sala plaisas (attiecīgi $22.0 \%$ un 36.2\%), ūdens zari (attiecīgi $50.5 \%$ un 65.8\%) un dakšošanās (attiecīgi 15.8\% un 23.5\%). Visiem nozāgeētajiem kokiem novērots iekrāsojums pirmā baḷka augstumā. Lobīšanai piemērotās koksnes īpatsvars bija pozitīvi saistīts ar nogriežna augstumu kokā un bija no $12 \%$ pirmajam nogrieznim līdz 33.4\% stumbra 30 m augstumā. Visas analizētās fenotipiskās pazīmes samazināja audzes finansiālo vērtību: sala plaisas par $6 \%$ līdz 8\%, citi ārēji novērtējamie stumbra defekti par $16 \%$ līdz 20\%, visas ārēji novērtējamās un iekšējās pazīmes kopā par $29 \%$ lìdz $33 \%$. 